\title{
Molecular Size Effects of Diarylnitrone Additive on the Refractive-Index Change in Poly(methyl methacrylate) Film
}

\author{
Kenta TANAKA, ${ }^{1, \dagger}$ Mariko FuKudA, ${ }^{2}$ Tetsutaro IgARASHI, ${ }^{2}$ and Tadamitsu SAKURAI ${ }^{2}$ \\ ${ }^{1}$ High-Tech Research Center, Kanagawa University, Kanagawa-ku, Yokohama 221-8686, Japan \\ ${ }^{2}$ Department of Applied Chemistry, Faculty of Engineering, Kanagawa University, \\ Kanagawa-ku, Yokohama 221-8686, Japan
}

(Received April 19, 2005; Accepted July 5, 2005; Published October 15, 2005)

\begin{abstract}
Through a UV spectral analysis of the photorearrangement reactions in hydroxy- and methoxy-substituted diarylnitrones, it was found that the maximum wavelength of the first absorption band in these nitrone derivatives solubilized into poly(methyl methacrylate) film can be used as a measure of the refractive-index change which is directly related to the change in linear polarizability. It was also found that steric bulkiness of the alkyl substituent attached at the para-position on the $N$-aryl benzene ring contributes to the magnitude of refractive-index change to only a negligible extent. [DOI 10.1295/polymj.37.776]

KEY WORDS Diarylnitrones / Photochemistry / Refractive Index / Polymer Film / Molecular Size /
\end{abstract}

Polymer optical devices have been frequently utilized instead of $\mathrm{SiO}_{2}$ glass devices because the former materials have advantages of easy casting, strong shock resistance, and low specific gravity. For example, it is well known that polymer optical fiber (POF) is one of the most important devices for optical communications. ${ }^{1,2}$ While POF material having lower transparency as compared to that of $\mathrm{SiO}_{2}$ glass optical fiber is not suitable for long-range optical communications, the fast transmission ability of POF material having also the advantages described above enables the utilization of this material for short-range optical communications.

Recently, much attention is being directed to the graded index-type POF material that displays large transmission ability and low attenuation in optical data communications. The refractive index profile characteristic of this POF material has mostly been produced by the interfacial polymerization of methyl methacrylate (MMA) in the presence of an additive possessing higher refractive index than that of MMA. ${ }^{3}$ Because the graded index-type POF material thus prepared is much more expensive as compared to standard communication devices, the photocontrol of polymer refractive index, making it possible to provide a simple and economical method for fabricating this type of POF material, has been the subject of extensive research efforts. ${ }^{4-6}$ Horie and his coworkers showed that photochemical transformations of norbornadienyl ${ }^{4}$ and cinnamoyl ${ }^{5}$ chromophores incorporated into transparent polymers are both effective for modulating polymer refractive indices. In their studies the refractive index was decreased because of $\pi$-conjugation greatly weakened by the photoisomerization. The modulation of polymer refractive index was achieved also by the photoisomerization of $\alpha$-(4-dimethylaminophenyl)- $N^{\prime}$-phenylnitrone as an additive to the corresponding oxaziridine derivative. ${ }^{6}$ It was concluded that one may generate refractive-index profile for graded index-type POF material by controlling irradiation light intensity and irradiation time.

In the previous study we attempted to photochemically control the refractive index of poly(methyl methacrylate) (PMMA) film doped with hydroxy-substituted diarylnitrone additives and succeeded in reducing its refractive index to the practical level and then in attaining the high stability of the polymer refractive index at any conversions of the starting nitrone into the corresponding rearrangement product. ${ }^{7}$ It was also found that an intramolecular hydrogen-bonding interaction lowers the excited-state reactivity of diarylnitrones by a factor of about 20 while the PMMA matrix greatly enhances the thermal stability of these nitrone derivatives. From the Lorentz-Lorenz equa$\operatorname{tion}^{8}(1)$ we see that if the number density of molecule $(N)$ remains constant during irradiation, refractive index $(n)$ is determined by the linear polarizability $(\alpha)$ of a given molecule, which is closely related to the molecular size. If we consider the significance of relationship between the refractive-index $(\Delta n)$ and molecular-size $(\Delta V)$ changes which are both caused by photochemical transformation, an investigation directed toward the elucidation of such a relationship will prove to be of great value from a practical point

${ }^{\dagger}$ To whom correspondence should be addressed (E-mail: kentat@k9.dion.ne.jp). 
of view. It is also significant to elucidate the role of the hydrogen-bonding interaction in the refractiveindex changes observed for PMMA film containing hydroxy-substituted diarylnitrone as an additive. For these ends we designed and synthesized $\alpha$-(2-hydroxysubstituted aryl)- $N$-(4-alkyl-substituted phenyl)nitrone derivatives $(\mathbf{1} \mathbf{a}-\mathbf{h})$ and their methoxy analogs $(\mathbf{1} \mathbf{i}-\mathbf{k})$. The data for 1a, $\mathbf{b}$ and $\mathbf{1 e}, \mathbf{f}$ used in this study are those obtained in the previous study. ${ }^{7}$

$$
\left(n^{2}-1\right) /\left(n^{2}+2\right)=(4 / 3) \pi N \alpha
$$

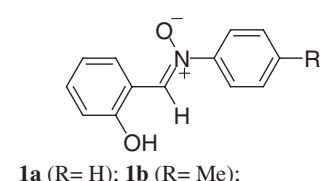

1a $(\mathrm{R}=\mathrm{H}) ; \mathbf{1 b}(\mathrm{R}=\mathrm{Me})$; 1c $\left(\mathrm{R}=\mathrm{CH}\left(\mathrm{CH}_{3}\right)_{2}\right) ; \mathbf{1 d}\left(\mathrm{R}=\mathrm{CH}_{2} \mathrm{Ph}\right)$

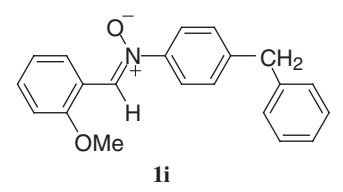

\section{EXPERIMENTAL}

\section{Materials and Solvents}

$\mathrm{N}$-Arylhydroxylamines were prepared by treating the corresponding nitrobenzene derivative with $\mathrm{Zn}$ dust in aqueous EtOH containing $\mathrm{NH}_{4} \mathrm{Cl}$. N-Arylhydroxylamine $(48 \mathrm{mmol})$ and 2-substituted-1-naphthaldehyde or 2-substituted benzaldehyde $(48 \mathrm{mmol})$ were dissolved in ethanol $(40 \mathrm{~mL})$ and stirred for $12-24 \mathrm{~h}$ at room temperature. Pale yellow crystals separated out were collected and recrystallized from ethanol or EtOAc-hexane. Physical and spectroscopic data of $\mathbf{1 c}, \mathbf{d}$ and $\mathbf{1 g}-\mathbf{k}$ are as follows.

$\alpha$-(2-Hydroxyphenyl)- $N$-(4-isopropylphenyl)nitrone (1c), mp 81.5-82.5 ${ }^{\circ} \mathrm{C} ;{ }^{1} \mathrm{H}$ NMR $\left(500 \mathrm{MHz}, \mathrm{CDCl}_{3}\right)$ : $\delta 12.56(1 \mathrm{H}, \mathrm{s}), 8.04(1 \mathrm{H}, \mathrm{s}), 7.68(2 \mathrm{H}, \mathrm{d}, J=8.6$ $\mathrm{Hz}), 7.43(1 \mathrm{H}, \mathrm{dd}, J=8.0,8.0 \mathrm{~Hz}), 7.33(2 \mathrm{H}, \mathrm{d}, J=$ $8.6 \mathrm{~Hz}), 7.17(1 \mathrm{H}, \mathrm{d}, J=8.0 \mathrm{~Hz}), 7.01(1 \mathrm{H}, \mathrm{d}, J=$ $8.0 \mathrm{~Hz}), 6.88(1 \mathrm{H}, \mathrm{dd}, J=8.0,8.0 \mathrm{~Hz}), 2.98(1 \mathrm{H}, \mathrm{q}$, $J=7.8 \mathrm{~Hz}), 1.27(6 \mathrm{H}, \mathrm{d}, J=7.8 \mathrm{~Hz}) ;{ }^{13} \mathrm{C}$ NMR $(125$ $\left.\mathrm{MHz}, \mathrm{CDCl}_{3}\right): \delta 159.9,151.8,144.0,140.6,134.5$, $132.8,127.3$ (2C), 121.8 (2C), 120.4, 119.2, 117.1, 33.9, 23.8 (2C). (Found: C, 75.25; H, 6.82; N, 5.48\%. Calcd for $\mathrm{C}_{16} \mathrm{H}_{17} \mathrm{NO}_{2}$ : C, 75.27; $\left.\mathrm{H}, 6.71 ; \mathrm{N}, 5.49 \%\right)$.

$\alpha$-(2-Hydroxyphenyl)- $N$-(4-benzylphenyl)nitrone (1d), mp $125.0-126.0^{\circ} \mathrm{C} ;{ }^{1} \mathrm{H}$ NMR $\quad(500 \mathrm{MHz}$, $\left.\mathrm{CDCl}_{3}\right): \delta 12.50(1 \mathrm{H}, \mathrm{s}), 8.03(1 \mathrm{H}, \mathrm{s}), 7.69(2 \mathrm{H}, \mathrm{d}, J=$ $8.6 \mathrm{~Hz}), 7.44(1 \mathrm{H}, \mathrm{dd}, J=8.0,8.0 \mathrm{~Hz}), 7.32(1 \mathrm{H}, \mathrm{dd}$, $J=7.0,7.0 \mathrm{~Hz}), 7.30(2 \mathrm{H}, \mathrm{d}, J=7.0 \mathrm{~Hz}), 7.23(1 \mathrm{H}$, d, $J=8.0 \mathrm{~Hz}), 7.18(2 \mathrm{H}, \mathrm{d}, J=8.6 \mathrm{~Hz}), 7.17(2 \mathrm{H}$, d, $J=7.0,7.0 \mathrm{~Hz}), 7.02(1 \mathrm{H}, \mathrm{d}, J=8.0 \mathrm{~Hz}), 6.89$
$(1 \mathrm{H}, \mathrm{dd}, J=8.0,8.0 \mathrm{~Hz}), 4.04(2 \mathrm{H}, \mathrm{s}) ;{ }^{13} \mathrm{C} \mathrm{NMR}$ $\left(125 \mathrm{MHz}, \mathrm{CDCl}_{3}\right): \delta 159.9,144.3,144.1,140.7$, $139.9,134.5,132.8,129.7$ (2C), 128.9 (2C), 128.7 (2C), 126.5, 121.8 (2C), 120.4, 119.2, 116.9, 41.4. (Found: C, 79.10; H, 5.50; N, 4.53\%. Calcd for $\mathrm{C}_{20} \mathrm{H}_{17} \mathrm{NO}_{2}$ : C, 79.19; H, 5.65; N, 4.62\%).

$\alpha$-(2-Hydroxy-1-naphthyl)- $N$-(4-isopropylphenyl)nitrone (1g), mp 128.0-129.0 ${ }^{\circ} \mathrm{C} ;{ }^{1} \mathrm{H}$ NMR $(500 \mathrm{MHz}$, $\left.\mathrm{CDCl}_{3}\right): \delta 12.54(1 \mathrm{H}, \mathrm{s}), 8.84(1 \mathrm{H}, \mathrm{s}), 7.91(1 \mathrm{H}, \mathrm{d}, J=$ $8.0 \mathrm{~Hz}), 7.79(1 \mathrm{H}, \mathrm{d}, J=8.0 \mathrm{~Hz}), 7.74(1 \mathrm{H}, \mathrm{d}, J=8.0$ $\mathrm{Hz}), 7.68(2 \mathrm{H}, \mathrm{d}, J=8.6 \mathrm{~Hz}), 7.50(1 \mathrm{H}, \mathrm{dd}, J=8.0$, $8.0 \mathrm{~Hz}), 7.40(1 \mathrm{H}, \mathrm{dd}, J=8.0,8.0 \mathrm{~Hz}), 7.38(2 \mathrm{H}, \mathrm{d}$, $J=8.6 \mathrm{~Hz}), 7.20(1 \mathrm{H}, \mathrm{d}, J=8.0 \mathrm{~Hz}), 3.00(1 \mathrm{H}, \mathrm{q}$, $J=6.9 \mathrm{~Hz}), 1.30(6 \mathrm{H}, \mathrm{d}, J=6.9 \mathrm{~Hz}) ;{ }^{13} \mathrm{C}$ NMR $(125$ $\left.\mathrm{MHz}, \mathrm{CDCl}_{3}\right): \delta 162.1,151.7,144.0,138.6,135.5$, 133.0, 129.1, 128.2, 127.9, 127.4 (2C), 123.9, 122.4, 121.8 (2C), 121.0, 108.9, 33.9, 23.8 (2C). (Found: C, 78.80; H, 6.35; N, 4.52\%. Calcd for $\mathrm{C}_{20} \mathrm{H}_{19} \mathrm{NO}_{2}$ : C, 78.66; H, 6.27; N, 4.59\%).

$\alpha$-(2-Hydroxy-1-naphthyl)- $N$-(4-benzylphenyl)nitrone (1h), mp $134.0-135.0^{\circ} \mathrm{C} ;{ }^{1} \mathrm{H}$ NMR $(500 \mathrm{MHz}$, $\left.\mathrm{CDCl}_{3}\right): \delta 13.89(1 \mathrm{H}, \mathrm{s}), 9.31(1 \mathrm{H}, \mathrm{s}), 8.17(1 \mathrm{H}, \mathrm{d}$, $J=8.6 \mathrm{~Hz}), 8.02(1 \mathrm{H}, \mathrm{d}, J=8.6 \mathrm{~Hz}), 7.98(1 \mathrm{H}, \mathrm{d}$, $J=8.6 \mathrm{~Hz}), 7.93(2 \mathrm{H}, \mathrm{d}, J=9.0 \mathrm{~Hz}), 7.66(1 \mathrm{H}, \mathrm{dd}$, $J=8.6,8.6 \mathrm{~Hz}), 7.51(1 \mathrm{H}, \mathrm{dd}, J=8.6,8.6 \mathrm{~Hz}), 7.45$ $(2 \mathrm{H}, \mathrm{d}, J=10.7 \mathrm{~Hz}), 7.41(1 \mathrm{H}, \mathrm{d}, J=8.6 \mathrm{~Hz}), 7.33$ $(1 \mathrm{H}, \mathrm{dd}, J=9.0,9.0 \mathrm{~Hz}), 7.32(2 \mathrm{H}, \mathrm{dd}, J=9.0$, $9.0 \mathrm{~Hz}), 7.27(2 \mathrm{H}, \mathrm{d}, J=10.7 \mathrm{~Hz}), 3.37(2 \mathrm{H}, \mathrm{s}) ;{ }^{13} \mathrm{C}$ NMR $\left(125 \mathrm{MHz}, \mathrm{CDCl}_{3}\right): \delta 162.2,144.3,143.9$, 139.9, 138.7, 135.6, 133.0, 129.8 (2C), 129.1, 128.9 (2C), 128.7 (2C), 128.2, 127.9, 126.5, 124.0, 122.4, 121.9 (2C), 121.0, 108.9, 41.4. (Found: C, 81.56; H, $5.42 ; \mathrm{N}, 3.96 \%$. Calcd for $\mathrm{C}_{24} \mathrm{H}_{19} \mathrm{NO}_{2}: \mathrm{C}, 81.56 ; \mathrm{H}$, $5.42 ; \mathrm{N}, 3.96 \%)$.

$\alpha$-(2-Methoxyphenyl)- $N$-(4-benzylphenyl)nitrone (1i), mp 85.5-86.5 ${ }^{\circ} \mathrm{C} ;{ }^{1} \mathrm{H}$ NMR $\left(500 \mathrm{MHz}, \mathrm{CDCl}_{3}\right): \delta$ $9.47(1 \mathrm{H}, \mathrm{d}, J=7.4 \mathrm{~Hz}), 8.36(1 \mathrm{H}, \mathrm{s}), 7.69(2 \mathrm{H}, \mathrm{d}$, $J=8.6 \mathrm{~Hz}), 7.41(1 \mathrm{H}, \mathrm{dd}, J=7.4,7.4 \mathrm{~Hz}), 7.31(2 \mathrm{H}$, d, $J=7.4 \mathrm{~Hz}), 7.27(2 \mathrm{H}, \mathrm{dd}, J=7.4,7.4 \mathrm{~Hz}), 7.22$ $(1 \mathrm{H}, \mathrm{dd}, J=7.4,7.4 \mathrm{~Hz}), 7.18(2 \mathrm{H}, \mathrm{d}, J=8.6 \mathrm{~Hz})$, $7.08(1 \mathrm{H}, \mathrm{dd}, J=7.4,7.4 \mathrm{~Hz}), 6.91(1 \mathrm{H}, \mathrm{d}, J=7.4$ $\mathrm{Hz}), 4.03(2 \mathrm{H}, \mathrm{s}), 3.87(3 \mathrm{H}, \mathrm{s}) ;{ }^{13} \mathrm{C}$ NMR $(125 \mathrm{MHz}$, $\left.\mathrm{CDCl}_{3}\right): \delta 157.4,147.9,143.0,140.3,132.1,129.5$ (2C), 129.1, 128.9 (2C), 128.7, 128.6 (2C), 126.4, 121.9 (2C), 120.8, 119.9, 109.8, 55.6, 41.5. (Found: C, 79.20; H, 6.14; N, 4.25\%. Calcd for $\mathrm{C}_{21} \mathrm{H}_{19} \mathrm{NO}_{2}$ : C, 79.47; H, 6.03; N, 4.41\%).

$\alpha$-(2-Methoxy-1-naphthyl)- $N$-(4-tolyl)nitrone (1j), mp $142.5-143.5^{\circ} \mathrm{C} ;{ }^{1} \mathrm{H}$ NMR $\left(500 \mathrm{MHz}, \mathrm{CDCl}_{3}\right): \delta$ $8.42(1 \mathrm{H}, \mathrm{s}), 7.98(1 \mathrm{H}, \mathrm{d}, J=9.2 \mathrm{~Hz}), 7.83-81(3 \mathrm{H}$, $\mathrm{m}), 7.72(1 \mathrm{H}, \mathrm{d}, J=8.0 \mathrm{~Hz}), 7.54(1 \mathrm{H}, \mathrm{dd}, J=6.9$, $8.3 \mathrm{~Hz}), 7.40(1 \mathrm{H}, \mathrm{dd}, J=6.9,8.0 \mathrm{~Hz}), 7.33-7.31$ $(3 \mathrm{H}, \mathrm{m}), 4.00(3 \mathrm{H}, \mathrm{s}), 2.47(3 \mathrm{H}, \mathrm{s}) ;{ }^{13} \mathrm{C}$ NMR $(125$ $\left.\mathrm{MHz}, \mathrm{CDCl}_{3}\right): \delta 157.1,146.5,140.3,132.7,131.2$, 130.6, 129.6 (2C), 128.8, 128.3, 127.1, 125.9, 124.0, 
121.9 (2C), 112.9, 112.2, 56.3, 21.2. (Found: C, 78.37; $\mathrm{H}, 5.93 ; \mathrm{N}, 4.79 \%$. Calcd for $\mathrm{C}_{19} \mathrm{H}_{17} \mathrm{NO}_{2}: \mathrm{C}, 78.33 ; \mathrm{H}$, $5.88 ; \mathrm{N}, 4.81 \%)$.

$\alpha$-(2-Methoxy-1-naphthyl)- $N$-(4-benzylphenyl)nitrone $(\mathbf{1 k}), \mathrm{mp} 133.0-134.0^{\circ} \mathrm{C} ;{ }^{1} \mathrm{H}$ NMR $(500 \mathrm{MHz}$, $\left.\mathrm{CDCl}_{3}\right): \delta 8.85(1 \mathrm{H}, \mathrm{s}), 8.44(1 \mathrm{H}, \mathrm{d}, J=8.6 \mathrm{~Hz})$, $8.32(2 \mathrm{H}, \mathrm{dd}, J=6.9,6.9 \mathrm{~Hz}), 8.29(1 \mathrm{H}, \mathrm{d}, J=8.6$ $\mathrm{Hz}), 8.18(1 \mathrm{H}, \mathrm{d}, J=8.6 \mathrm{~Hz}), 8.01(1 \mathrm{H}, \mathrm{dd}, J=8.0$, $8.6 \mathrm{~Hz}), 7.87(1 \mathrm{H}, \mathrm{dd}, J=8.0,8.0 \mathrm{~Hz}), 7.83(2 \mathrm{H}, \mathrm{d}$, $J=6.9 \mathrm{~Hz}), 7.81(1 \mathrm{H}, \mathrm{dd}, J=6.9,6.9 \mathrm{~Hz}), 7.77$ $(1 \mathrm{H}, \mathrm{d}, J=8.6 \mathrm{~Hz}), 7.74(2 \mathrm{H}, \mathrm{d}, J=6.9 \mathrm{~Hz}), 7.70$ $(2 \mathrm{H}, \mathrm{d}, J=6.9 \mathrm{~Hz}), 4.49(2 \mathrm{H}, \mathrm{s}), 4.42(3 \mathrm{H}, \mathrm{s}) ;{ }^{13} \mathrm{C}$ $\operatorname{NMR}\left(125 \mathrm{MHz}, \mathrm{CDCl}_{3}\right): \delta 157.2,147.0,143.5$, $140.3,132.8,131.3,130.5,129.5$ (2C), 128.9 (2C), $128.8,128.7$ (2C), 128.3, 127.1, 126.4, 125.9, 124.0, 122.2 (2C), 112.8, 112.2, 56.2, 41.5. (Found: C, 81.70; H, 5.80; N, 3.86\%. Calcd for $\mathrm{C}_{25} \mathrm{H}_{21} \mathrm{NO}_{2}$ : C, 81.72; H, 5.76; N, 3.81\%).

Poly(methyl methacrylate) (PMMA; Wako Pure Chemicals Co. Ltd., $n=1000-1500$ ) as a host polymer was used without further purification. Acetonitrile as a solvent was purified according to the standard method. All other chemicals employed were obtained from commercial sources and were of the highest grade available. PMMA films containing $20 \mathrm{wt} \%$ of $\mathbf{1 a}-\mathbf{j}$ were prepared by spin coating of a 2-methoxyethyl acetate solution on a silica glass (for UV spectral measurements) and on a silicon wafer (for refractive index measurements), followed by vacuum drying at $40^{\circ} \mathrm{C}$.

\section{Measurements}

UV absorption spectra were recorded on a Hitachi U-3300 spectrophotometer. ${ }^{1} \mathrm{H}$ and ${ }^{13} \mathrm{C}$ NMR spectra were taken with a JEOL JNM-A500 spectrometer using tetramethylsilane as an internal standard. Solutions or polymer films containing $\mathbf{1 a}-\mathbf{k}$ were irradiated with $366 \mathrm{~nm}$ light from a $450 \mathrm{~W}$ high-pressure $\mathrm{Hg}$ lamp. This monochromatic light was selected by employing Corning 0-52, Corning 7-60, and Toshiba IRA-25S glass filters.

Refractive indices of the films were measured before and after irradiation with a Gaertner L115B elipsometer. The light source for refractive-index measurements was a $632.8 \mathrm{~nm} \mathrm{He}-\mathrm{Ne}$ laser.

\section{RESULTS AND DISCUSSIONS}

\section{Photoreactivity in Solution}

It was previously shown that the photoisomerization of 1-naphthyl-substituted nitrone procceds to quantitatively give the oxaziridine derivative, ${ }^{9}$ thus allowing us to expect that the irradiation of hydroxyor methoxy-substituted diarylnitrones (1) affords the corresponding oxadiridines in excellent yields. In Figure 1 are typically shown UV absorption spectral

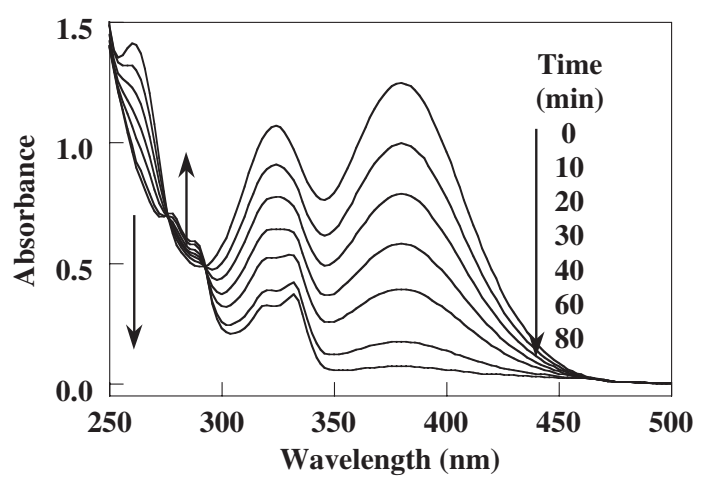

Figure 1. UV absorption spectral changes caused by the irradiation at $366 \mathrm{~nm}$ of a nitrogen-saturated acetonitrile solution of $\mathbf{1 f}$ $\left(1.0 \times 10^{-4} \mathrm{~mol} \mathrm{dm}^{-3}\right)$ at room temperature.

changes caused by the $366 \mathrm{~nm}$ irradiation of a nitrogen-saturated acetonitrile solution of $\mathbf{1 f}$ at room temperature. When the photoreaction went to completion, the strong UV absorption of the starting $\mathbf{1 f}$ at $379 \mathrm{~nm}$ virtually disappeared with appearance of the $330 \mathrm{~nm}$ absorption, while there were two isosbestic points at 275 and $293 \mathrm{~nm}$. This observation indicates the clean reaction to proceed yielding a single product. However, the isolated product existed as two conformers in solution ( ${ }^{1} \mathrm{H}$ NMR spectral analysis), it was very difficult to unambiguously determine its structure. An $\mathrm{X}$-ray analysis of the single crystal established that the photorearrangement of $\mathbf{1 f}$ proceeds to selectively afford $N$-(2-hydroxynaphthyl)- $N$-(4-tolyl)formamide (2f), as shown in Scheme $1 .{ }^{10}$ Similar UV absorption and ${ }^{1} \mathrm{H}$ NMR spectral behavior was observed for the other hydroxy-substituted nitrone derivatives $(\mathbf{1 a}-\mathbf{h})$, demonstrating that these derivatives undergo selective rearrangement reactions leading to the corresponding $\mathrm{N}, \mathrm{N}$-diarylformamides, possibly, through oxaziridine intermediates. It was also found in the previous study that the replacement of the hydroxy group in $\mathbf{1 f}$ by the methoxy $(\mathbf{1 j})$ induces another type of the rearrangement affording the 1-naphthanilide derivative in addition to the above-mentioned rearrangement reaction. ${ }^{10}$ As shown in Chart 1, an intramolecular hydrogen bonding in $\mathbf{1 f}$ is considered to play a pivotal role in controlling the bond-cleavage mode in a given oxaziridine intermediate. The finding that there is only a very small difference in UV absorption between the 1f-derived $N, N$-diarylformamide and 1-naphthanilide derivatives indicates the thermal conversion of an oxadiridine intermediate into these derivatives to exert a negligible effect upon the extent of $\pi$-conjugation. In addition, a comparison of UV absorption spectra for $\mathbf{1 f}$ (Figure 1) and its methoxy analog (1j, Figure 2) confirms that the presence of an intramolecular hydrogen-bonding interaction, namely, stabilization of $\mathbf{1 f}$ by this hydrogen-bonding interaction affects both 


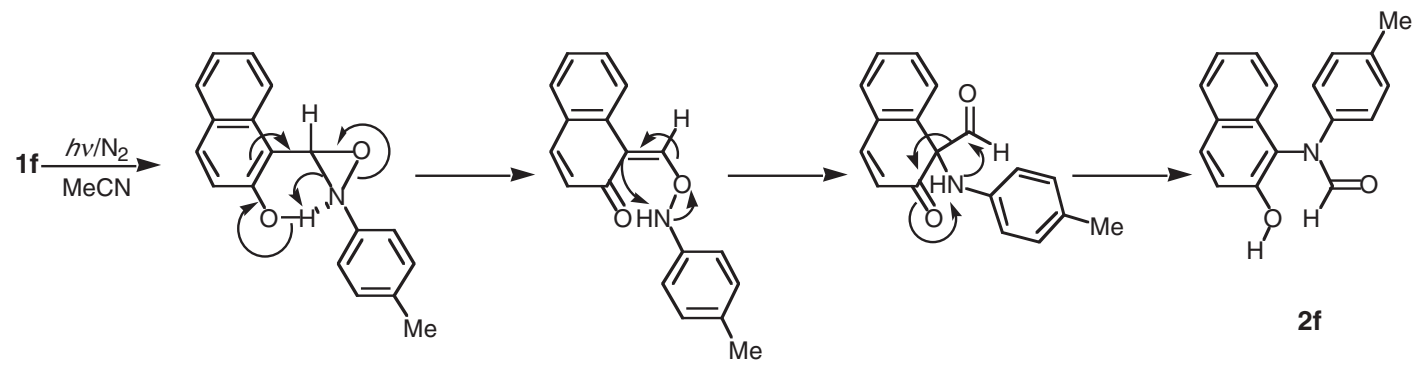

Scheme 1.

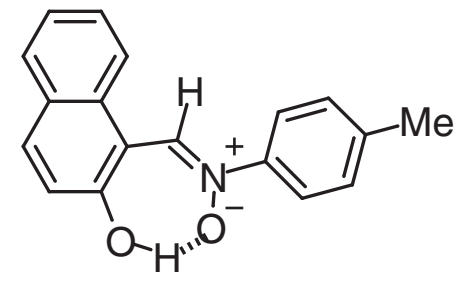

Chart 1.

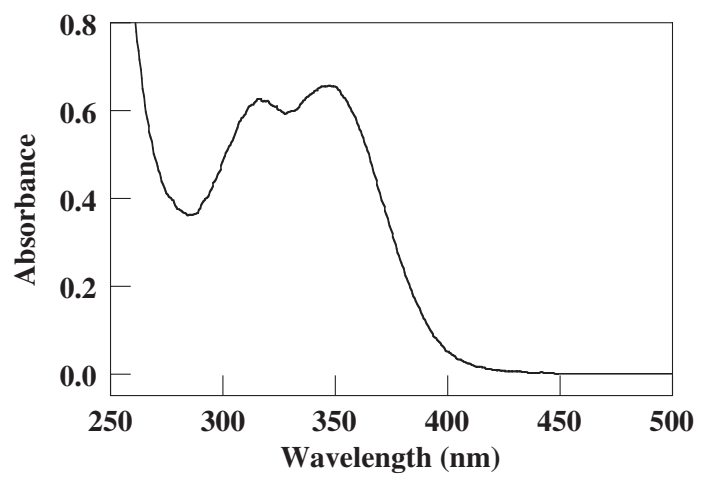

Figure 2. UV absorption spectrum of $\mathbf{1 j}\left(1.0 \times 10^{-4} \mathrm{~mol}\right.$ $\mathrm{dm}^{-3}$ ) in acetonitrile at room temperature.

intensity and shape of the first absorption band. The same argument applies well also to the UV absorption bands observed for $\mathbf{1 d}$ and $\mathbf{1 i}$ or for $\mathbf{1 h}$ and $\mathbf{1 k}$. Because alkyl substituents introduced at the paraposition on the $N$-aryl benzene ring exert negligible effects on the UV absorption spectra, we were led to conclude that the extent of $\pi$-conjugation is affected by these substituents to, if any, only a small extent $\left(\lambda_{\max }\right.$ and $\varepsilon_{\max }$, Table I).

\section{Photoreactivity in PMMA Film}

PMMA films containing $20 \mathrm{wt} \%$ of $\mathbf{1 a}-\mathbf{k}$ were prepared on silica glasses for their UV spectral measurements. The thickness of transparent films was about $0.1 \mu \mathrm{m}$. As already described in the Introduction, hydrogen bonding formed between the hydroxy hydrogen and the $N$-oxide oxygen contributed greatly toward lowering the excited-state reactivity of hydroxysubstituted diarylnitrones. While the observation of significantly increased reactivity of these nitrones in
Table I. Maximum wavelength $\left(\lambda_{\max }\right)$ and molar extinction coefficient $\left(\varepsilon_{\max }\right)$ for the first absorption band of $\mathbf{1 a}-\mathbf{k}$ in acetonitrile

\begin{tabular}{ccc}
\hline Compound & $\begin{array}{c}\lambda_{\max } \\
(\mathrm{nm})\end{array}$ & $\begin{array}{c}\varepsilon_{\max } \times 10^{-4} \\
\left(\mathrm{dm}^{3} \mathrm{~mol}^{-1} \mathrm{~cm}^{-1}\right)\end{array}$ \\
\hline $\mathbf{1 a}$ & 354 & 0.74 \\
$\mathbf{1 b}$ & 354 & 0.85 \\
$\mathbf{1 c}$ & 355 & 0.89 \\
$\mathbf{1 d}$ & 356 & 0.93 \\
$\mathbf{1 e}$ & 379 & 1.17 \\
$\mathbf{1 f}$ & 378 & 1.25 \\
$\mathbf{1 g}$ & 381 & 1.22 \\
$\mathbf{1 h}$ & 381 & 1.31 \\
$\mathbf{1 i}$ & 343 & 1.92 \\
$\mathbf{1 j}$ & 348 & 0.66 \\
$\mathbf{1 k}$ & 349 & 0.93 \\
\hline
\end{tabular}

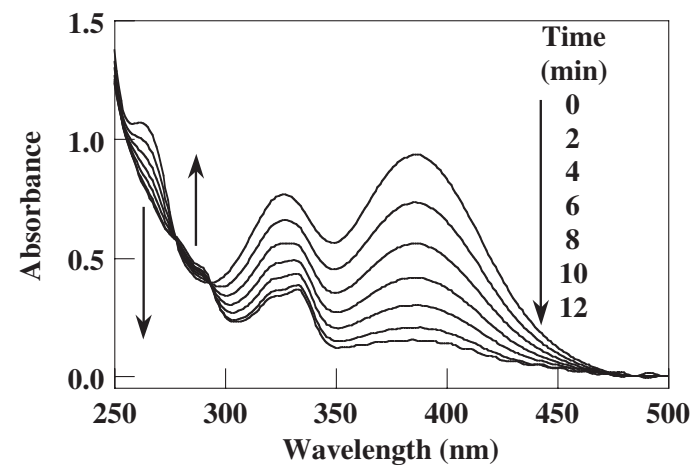

Figure 3. UV absorption spectral changes of 1f $(20 \mathrm{wt} \%)$ caused by its irradiation at $366 \mathrm{~nm}$ in PMMA film at room temperature.

PMMA film was explained in terms of the weakened intramolecular hydrogen bond in this film, UV absorption spectra of $\mathbf{1 f}$ in $\mathrm{MeCN}$ (Figure 1) and PMMA (Figure 3) are very similar to each other, indicating the intramolecular hydrogen bond to be formed even in the latter polymer film. The finding that the excited-state reactivities of $\mathbf{1 f}$ and $\mathbf{1 j}, \mathbf{1 d}$ and $\mathbf{1 i}$ or $\mathbf{1 h}$ and $1 \mathbf{k}$ are both enhanced in PMMA film by about an order of magnitude strongly suggests the more increased nucleophilicity of the excited-state $\mathrm{N}$-oxide oxygen in this polymer film than in solution. It is thus very likely that photoreaction in the former state gives 
the same product distribution as that observed in the latter state, though there are some indications of secondary reactions especially in the methoxy-substituted diarylnitrones.

\section{Changes in the Refractive Index of PMMA Film and} the Molecular Size of Additive

Our attention is now directed to the relationship between the magnitudes of changes in refractive index $(\Delta n)$ and molecular size $(\Delta V)$, which are mainly caused by the photoisomerization of $\mathbf{1 a}-\mathbf{k}$ into the corresponding oxaziridine intermediates. If we consider that a $\pi \rightarrow \pi^{*}$ transition is responsible for the first absorption band of $\mathbf{1}$, the linear polarizability, namely, polarizability volume, of a given nitrone derivative may be correlated to the extent to which $\pi$-electron spreads over its derivative, that is, the extent of $\pi$-conjugation. Because the maximum wavelength $\left(\lambda_{\max }\right)$ of this absorption band reflects the magnitude of $\pi$-conjugation and then the photoproduct exhibits only a weak absorption at this wavelength, the $\lambda_{\max }$ value can be used as a measure of the polarizability-volume change, i.e., the $\Delta V$.

PMMA films containing $20 \mathrm{wt} \%$ of $\mathbf{1 a}-\mathbf{k}$, the thickness of which was about $0.1 \mu \mathrm{m}$, were similarly prepared on silicon wafers for their refractive-index measurements. In Table II are summarized the $\lambda_{\max }$ values of the starting nitrone derivatives and the magnitudes of $\Delta n$ caused by the prolonged irradiation which completes the photoisomerization. As seen from the Lorentz-Lorenz equation (1), the variation of PMMA film thickness with irradiation affects the number density of molecule $(N)$ directly and, hence, eventually the refractive index of the polymer film. For this reason the ratio at which the relative thickness of this film is decreased on irradiation is included in this Table. Plots of $-\Delta n$ against $\lambda_{\max }$ depicted in

Table II. Maximum wavelength $\left(\lambda_{\max }\right)$ for the first absorption band of 1a-k in PMMA film and refractive-index change $(-\Delta n)$ of this film caused by irradiation

\begin{tabular}{cccc}
\hline Compound & $\lambda_{\max }(\mathrm{nm})$ & $-\Delta n$ & Film thickness $^{\mathrm{a}}$ \\
\hline $\mathbf{1 a}$ & 359 & 0.009 & 94 \\
$\mathbf{1 b}$ & 359 & 0.009 & 92 \\
$\mathbf{1 c}$ & 361 & 0.005 & 86 \\
$\mathbf{1 d}$ & 362 & 0.008 & 93 \\
$\mathbf{1 e}$ & 387 & 0.013 & 96 \\
$\mathbf{1 f}$ & 386 & 0.014 & 96 \\
$\mathbf{1 g}$ & 387 & 0.007 & 80 \\
$\mathbf{1 h}$ & 388 & 0.010 & 96 \\
$\mathbf{1 i}$ & 346 & 0.005 & 82 \\
$\mathbf{1 j}$ & 354 & 0.005 & 98 \\
$\mathbf{1 k}$ & 355 & 0.007 & 93 \\
\hline
\end{tabular}

${ }^{a}$ Film thickness relative to that (100) of the unirradiated PMMA.

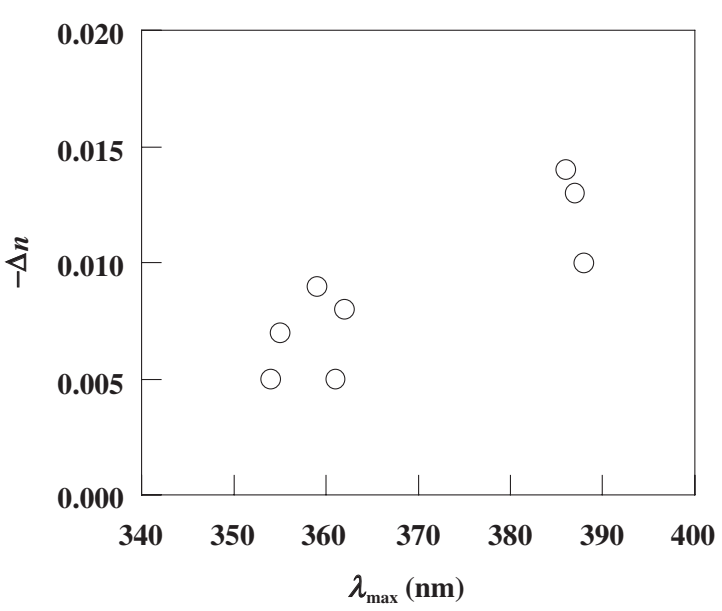

Figure 4. The magnitude of refractive-index change $(-\Delta n)$ caused by the irradiation of PMMA film containing $\mathbf{1 a}-\mathbf{f}, \mathbf{h}, \mathbf{j}, \mathbf{k}$ $(20 \mathrm{wt} \%)$ as a function of the maximum wavelength $\left(\lambda_{\max }\right)$ for the first absorption band of $\mathbf{1}$ solubilized into this polymer film.

Figure 4, where data for $\mathbf{1 g}$ and $\mathbf{1} \mathbf{i}$ were omitted owing to their much larger decrease in relative film thickness, revealed that the magnitude of $-\Delta n$ has a strong tendency to increase as $\lambda_{\max }$ is shifted to longer wavelengths. This is consistent with the minor contribution of linear polarizability for the photoproducts, $N, N$ diarylformamides and/or arylanilides. The refractive indices for 2-hydroxy-1-naphthyl-substituted nitrones show larger changes than those for the 2-hydroxyphenyl-substituted derivatives, as expected from the greater polarizability of naphthyl substituent in the former nitrones. On the other hand, it is worthwhile to consider the relationship between the steric bulkiness of the alkyl substituent $\mathrm{R}$ in $\mathbf{1}$ and the magnitude of $-\Delta n$. The data collected in Table II demonstrate that there is not clear relationship between these two parameters in any hydroxyphenyl- and hydroxynaphthyl-substituted nitrones, even if we consider the decrease in the relative film thickness of about 4-20\%. This may be due to the negligible contribution of steric bulkiness for the substituent $\mathrm{R}$ to the overall polarizability-volume change caused by the photochemical transformation of a given nitrone derivative. Since it was already established in the previous paper that the refractive index of PMMA-1f-derived film is very stable at any photochemical conversions of this additive, variability in refractive index as well as volatility from polymer surface led us to conclude that naphthyl-substituted nitrone derivatives are better additives to choose for the fabrication of graded indextype POF materials.

Acknowledgment. This research was partially supported by a "High-Tech Research Project" from the Ministry of Education, Culture, Sports, Science and Technology, Japan. 


\section{REFERENCES}

1. W. Daum, J. Krauser, P. E. Zamzow, and O. Ziemann, "POF-Polymer Optical Fibers for Data Communication," Springer, 2002.

2. N. G. Lekishvili, L. I. Nadareishvili, G. E. Zaikov, and L. M. Khananashvili, "Polymers and Polymeric Materials for Fiber and Gradient Optics," Brill Academic Publishers, 2002.

3. Y. Koike, E. Nihei, N. Tanio, and Y. Ohtsuka, Appl. Opt., 29, 2686 (1990).

4. K. Kinoshita, K. Horie, S. Morino, and T. Nishikubo, Appl. Phys. Lett., 70, 2940 (1997).
5. S. Murase, K. Kinoshita, K. Horie, and S. Morino, Macromolecules, 30, 8088 (1997).

6. T. Kada, A. Obara, T. Watanabe, S. Miyata, C. X. Liang, H. Machida, and K. Kiso, J. Appl. Phys., 87, 638 (2000).

7. K. Tanaka, K. Shima, H. Kondoh, T. Igarashi, and T. Sakurai, J. Appl. Polym. Sci., 93, 2517 (2004).

8. G. H. Meeten, "Optical Properties of Polymers," Springer, 1899.

9. Y. Ohba, K. Kubo, and T. Sakurai, J. Photochem. Photobiol., A, 113, 45 (1998).

10. H. Kondo, K. Tanaka, K. Kubo, T. Igarashi, and T. Sakurai, Heterocycles, 63, 241 (2004). 